\title{
Enhanced Response of the Fricke Solution Doped with Hematoporphyrin Under X-Rays Irradiation
}

\author{
Carlos Austerlitz ${ }^{1}$, Vivianne Lúcia Bormann de Souza ${ }^{1}$, Diana Maria Tavares Campos ${ }^{1}$, \\ Cristina Kurachi ${ }^{2}$ and Vanderley Bagnato ${ }^{2}$, Cláudio Sibata ${ }^{3}$ \\ ${ }^{1}$ Centro Regional de Ciências Nucleares, Rua Cônego Barata, 999 Recife, PE, CEP 52110-120, BRAZIL; \\ ${ }^{2}$ Universidade de São Paulo, Av. Trabalhador São Carlense, 400, São Carlos, SP, CEP 13566-590, BRAZIL; ${ }^{3}$ Brody \\ School of Medicine at ECU, Department of Radiation Oncology, Greenville, NC 27834, USA;
}

\begin{abstract}
The vials filled with Fricke solutions were doped with increasing concentrations of Photogem ${ }^{\circledR}$, used in photodynamic therapy. These vials were then irradiated with low-energy X-rays with doses ranging from 5 to 20 Gy. The conventional Fricke solution was also irradiated with the same doses. The concentration of ferric ions for the Fricke and doped-Fricke irradiated solutions were measured in a spectrophotometer at 220 to $340 \mathrm{~nm}$. The results showed that there was an enhancement in the response of the doped-Fricke solution, which was proportional to the concentration of the photosensitizer. The use of such procedure for studying the radiosensitizing property of photosensitizers based on the production of free radicals is also discussed.
\end{abstract}

Key words: Photodynamic therapy, hematoporphyrin, Fricke dosimeter, free radicals

\section{INTRODUCTION}

Photodynamic therapy (PDT) is a relative new treatment used for different types of the tumors (Dougherty, 1993, Sibata et al., 2000), in which a photosensitizing agent is injected into the patient bloodstream or topically applied to the patient skin promoting drug accumulation preferentially in the tumor. After 24 to $72 \mathrm{~h}$, the tumor is exposed to a visible laser light (wavelength around $630 \mathrm{~nm}$ ). The photosensitizing molecules absorb the light and produces free radicals and singlet oxygen that destroy the cancer cells.

Photosensitizers have a stable electronic configuration corresponding to a singlet state in their ground-state energy level. Following the absorption of a visible light photon, the molecule is promoted to an excited state, which is also a singlet state and is short-lived. The photosensitizer returns to the ground state by emitting a photon or by internal conversion with energy loss as heat. It is also possible that the molecule may convert to the triplet state via an intersystem crossing, which involves a change in the spin of an electron. This alternative is the one relevant to PDT.

There are basically two mechanisms, Type I and Type II reactions, by which the triplet state photosensitizer can react with the biomolecules promoting cellular damage (Oleinick and Evans, 1998). Type I reaction involves the transfer of the electron, or hydrogen atoms producing radical forms of the photosensitizer, or the substrate (Oleinick and Evans, 1998; Fritsch and Ruzicka, 2003). These radicals then react rapidly, usually with oxygen, resulting in the production of highly reactive oxygen species, such as superoxide

\footnotetext{
${ }^{*}$ Author for correspondence
} 
$\left(\mathrm{O}_{2}{ }^{--}\right)$(Oleinick and Evans, 1998), the peroxide anions $\left(\mathrm{O}_{2}{ }^{2-}\right)$ (Oleinick and Evans, 1998; Haylett et al., 2003), hydroxyl radicals ( $\mathrm{OH}^{-}$) (Haylett et al., 2003; Schaffer et al., 2005) and hydrogen peroxide $\left(\mathrm{H}_{2} \mathrm{O}_{2}\right)$ (Haylett et al., 2003). Type II reactions produce the electronically excited and highly reactive state of oxygen known as singlet oxygen $\left({ }^{1} \mathrm{O}_{2}{ }^{0}\right)$ (Wilson, 2002). Direct interaction of the excited triplet state photosensitizer with the molecular oxygen (which, unusually, has a triplet ground state) results in the photosensitizer returning to its singlet ground state and the formation of singlet oxygen, which acts as the cytotoxic agent. The relative weight of each type mechanism is still under debate.

Besides being an exciting new technique for the cancer treatment, the PDT has opened up new possibilities to enhance the conventional radiotherapy due to its synergistic ionizing radiation effects when the target tissue is photosensitized with the hematoporphyrin normally employed in the PDT (Schaffer et al, 2002a), The effect on the normal skin of this combined modality of the treatment has been reported as producing significant increase of skin necrosis (Benstead and Moore, 1990). The modification of radiosensitivity by porphyrins derivatives in several in vivo and in vitro experiments have also been studied (Schaffer et al., 2001; Schaffer et al., 2002; Schaffer et al., 2003; Schaffer et al., 2005; Moan and Petersen, 1981; Bellnier and Dougherty 1986; Zhao et al., 1986; Zhang et al., 1996; Kostron et al., 1986; Chen, 1985; Colasanti et al., 2004; Lukšiené, 2004). The mechanism of this radiosensitizing effect is not completely understood (Schaffer et al., 2005). In vitro data, however, support the hypothesis that the radiosensitizing action involves OH-radicals (Jori, 1996) in addition to a potential impairment of repair mechanisms after sub lethal damage of ionizing radiation (Schaffer et al., 2005).

To our knowledge, little has been published in the enhancement of the radiation effect due to the presence of photosensitizer for in vitro studies using chemical procedures. The Fricke dosimeter (Klassen et al., 1999) is based on the oxidation of the ferrous ions $\left(\mathrm{Fe}^{2+}\right)$ to ferric ions $\left(\mathrm{Fe}^{3+}\right)$, caused by the formation of the free radicals (FR) when the solution is irradiated by the ionizing radiation. Because the hematoporphyrin acts as radiosensitizer and produces FR under irradiation with ionizing radiation, this work had the aim to use a Fricke solution doped with Photogem ${ }^{\circledR}$ to test its sensitivity for those free radicals produced by the hematoporphyrin under the X-ray irradiation which yielded $\mathrm{Fe}^{3+}$.

\section{MATERIALS AND METHODS}

\section{Irradiation Setup}

An X-ray beam from a Pantak x-ray tube set at 70 $\mathrm{kV}$ with a $1.03-\mathrm{mm}$ aluminium filter was used to irradiate all the samples in the present work. The energy was verified with a Eurisys (Hewlett Packard) Ge spectrometer. The X-ray beam halfvalue layer was measured to be $3.1 \mathrm{~mm}$ of aluminium. The ionization chamber and the Fricke dosimeter (with and without the photosensitizer) were set at a distance of $500 \mathrm{~mm}$, at the central axis of the X-rays beam which was defined as $75 \mathrm{x}$ $75 \mathrm{~mm}$ at the calibration distance.

\section{Absorbed Dose determination}

The mean value of a set of five measurements made with a PTW type 2232 plane-parallel ionisation chamber inserted in a Plexiglas phantom (110 mm long, $110 \mathrm{~mm}$ wide and $80 \mathrm{~mm}$ deep) was used to calculate the absorbed dose to water. Another Plexiglas phantom with the same physical dimensions, appropriate to fit the vacutainers, was used to irradiate the vials with the Fricke dosimeter and Photogem ${ }^{\circledR}$ doped Fricke solutions. The doses delivered to the Fricke solution and the Photogem ${ }^{\circledR}$ doped Fricke solutions were based on the readings of a transmission ionisation chambers connected to a Farmer NE type 2670 electrometer.

\section{Standard and the Photogem ${ }^{\circledR}$ doped-Fricke solutions}

The Fricke solution was prepared with $0.392 \mathrm{~g}$ of $\left(\mathrm{NH}_{4}\right)_{2} \mathrm{Fe}\left(\mathrm{SO}_{4}\right)_{2} .6 \mathrm{H}_{2} \mathrm{O}, 0.060 \mathrm{~g}$ of $\mathrm{NaCl}, 22 \mathrm{ml}$ of $\mathrm{H}_{2} \mathrm{SO}_{4}$ and made up to $1,000 \mathrm{ml}$ with Milli-Q water $(18.2 \mathrm{M} \Omega . \mathrm{cm})$. The reference Photogem ${ }^{\circledR}$ doped Fricke solution was prepared by adding $0.0015 \mathrm{~g}$ of Photogem ${ }^{\circledR}$ to $1,000 \mathrm{ml}$ of Fricke solution. This solution was diluted to prepare solutions with concentrations of 2,4 and $6 \mathrm{mg} / \mathrm{l}$. A volume of $3 \mathrm{ml}$ of Fricke solution and Photogem ${ }^{\circledR}$ doped Fricke solutions were transferred to a $10 \mathrm{ml}$ sterile vacutainer using a needle coupled to a 
polypropylene tube. The irradiated solutions were transferred directly from the vacutainer to a 10 $\mathrm{mm}$ length curvette and the optical densities were measured in the range of 220 to $340 \mathrm{~nm}$ using a Beckman Counter Model DU 640 spectrophotometer.

As a first approximation, the doses obtained with the Fricke solution were calculated according to equations 1, 2 and 3 (Olszanski et al., 2002; IAEA, 1977; Klassen et al., 1999)

$$
\begin{aligned}
& D_{W}=\frac{\Delta O D \cdot N_{A}}{G\left(F_{e}^{3+}\right) \cdot \varepsilon\left(t^{o} C\right) \cdot d \cdot \rho \cdot f_{1} \cdot f_{2}} \\
& f_{1}=1+0,0069\left(T_{R}-25\right) \quad \text { Eq. } 2 \\
& f_{2}=1+0,0012\left(T_{i}-25\right) \quad \text { Eq. } 3
\end{aligned}
$$

Where $\varepsilon$ is the molar extinction coefficient of $\mathrm{Fe}^{3+}$ at $25{ }^{\circ} \mathrm{C}\left(218.7 \mathrm{~m}^{2} \mathrm{~mol}^{-1}\right)$ (Attix, 1986), $\mathrm{N}_{\mathrm{A}}$ is the Avogadro's number, $\mathrm{d}$ is the optical pathway (10 $\mathrm{mm}), \rho$ is the solution density $\left(1,022.7 \mathrm{~kg} \cdot \mathrm{m}^{-3}\right)$ (Olszanski et al., 2002). The factors $f_{1}$ and $f_{2}$ were used to correct the OD dependence with the temperatures, $\mathrm{T}_{\mathrm{i}}\left({ }^{\circ} \mathrm{C}\right)$, of the solution during the irradiation, and $\mathrm{T}_{\mathrm{R}}\left({ }^{\circ} \mathrm{C}\right)$ during the measurement . The value for the chemical yield, the $\mathrm{G}\left(\mathrm{Fe}^{3+}\right)=$ $8.93 \times 10^{17} \mathrm{~J}^{-1}$, was taken from ICRU Report 17 for dosimetry of X-Rays Generated at Potentials of 5 to $150 \mathrm{kV}$ (ICRU, 1970).

The change in the irradiated solution's optical density, $\triangle O D$, relative to the non-irradiated solution at a wavelength of $304 \mathrm{~nm}$ (absorption peak of $\mathrm{Fe}^{3+}$ ), of the Fricke solution was calculated by subtraction of the average optical density of the control (non irradiated Fricke solution). The change in the optical density (304 nm) of the doped-Fricke solution was obtained by subtraction of the average optical density of the non irradiated doped-Fricke solution.

\section{Long and short term consistency and reproducibility}

The long and short term consistency and reproducibility of the Photogem ${ }^{\circledR}$ doped Fricke solution was evaluated by irradiating $500 \mathrm{ml}$ solution with approximately $40 \mathrm{~Gy}$. The solution was stored at room temperature $\left(25-29{ }^{\circ} \mathrm{C}\right)$, and the optical densities measurements were made during a period of $480 \mathrm{~h}$.

\section{RESULTS AND DISCUSSION}

\section{General overview}

Fig. 1 shows the spectrum of the irradiated Photogem ${ }^{\circledR}$ doped Fricke solution (PDFS). These spectra were obtained from the Fricke solution doped with $2.5 \mathrm{mg} / \mathrm{l}$ of Photogem ${ }^{\circledR}$ and irradiated with doses of 5, 7.5, 10, 12.5 and $15 \mathrm{~Gy}$. The spectra of the PDFS were quite similar as those observed for the conventional Fricke dosimeter. The maximum optical densities values occured around 224 and $304 \mathrm{~nm}$, indicating that the maximum peaks absorption were due to the presence of ferric ions $\left(\mathrm{Fe}^{3+}\right)$ in the solution.

Fig. 2 shows the short and long term consistency and reproducibility of a Fricke solution doped with $2.5 \mathrm{mg} / \mathrm{l}$ Photogem $^{\circledR}$ irradiated with $40 \mathrm{~Gy}$. Results showed an oxidative process in order of $0.013 \% / \mathrm{h}$, which resulted in an increase in the response of the doped Fricke solution of $7 \%$. Comparable with the conventional stability of the Fricke dosimeter, this value was considerably higher, since the long term stability of the Fricke dosimeter, irradiated with the same X-ray beam quality, was in order of $\pm 1.8 \%$ during a period of about $600 \mathrm{~h}$. This meant that the presence of the photosensitizer affected the reproducibility of the Fricke dosimeter.

Fig. 3 shows the net optical density of the Fricke and Photogem ${ }^{\circledR}$ doped Fricke solution as a function of the absorbed dose ranged from 7 to 20 Gy when the Fricke solution (1 liter) was doped with 2, 4 and $6 \mathrm{mg}$ of Photogem ${ }^{\circledR}$. Higher concentration of the Photogem ${ }^{\circledR}$ in the Fricke solution, showed steeper slope of the curve. However, when the concentration of the Photogem ${ }^{\circledR}$ was $6 \mathrm{mg} / \mathrm{l}$, the solution became darker with some precipitation drifting within the solution, which indicated a possible limitation of this method. 


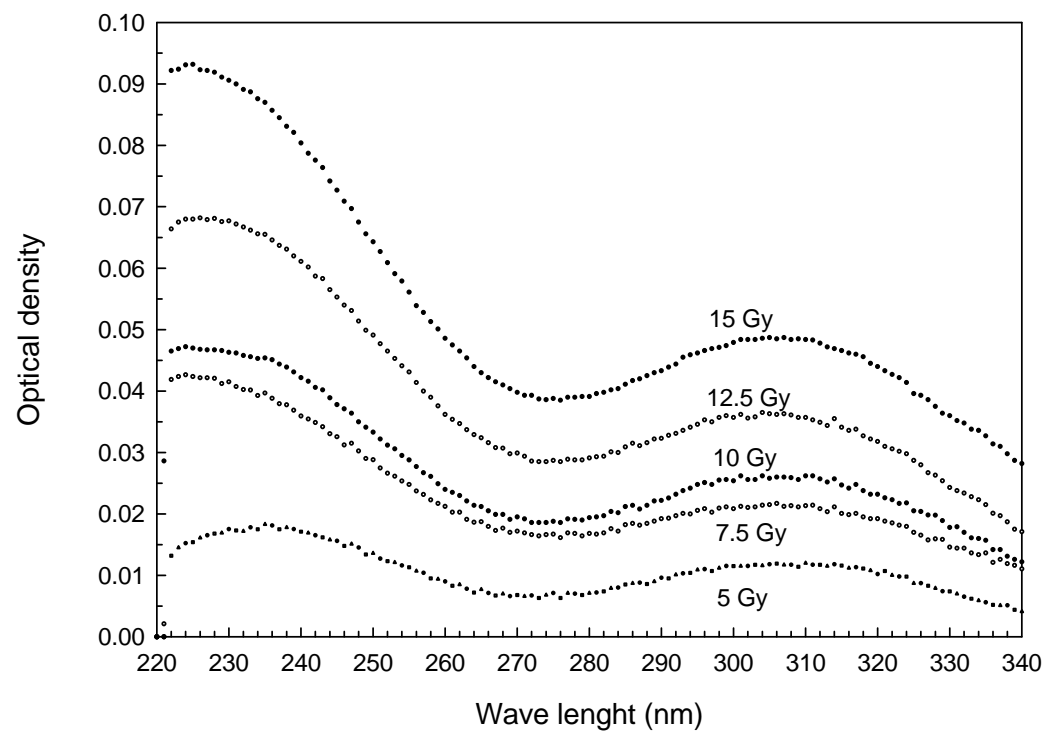

Figure 1 - Spectra of Photogem ${ }^{\circledR}$ doped Fricke solutions irradiated with doses between 5 and 15 Gy

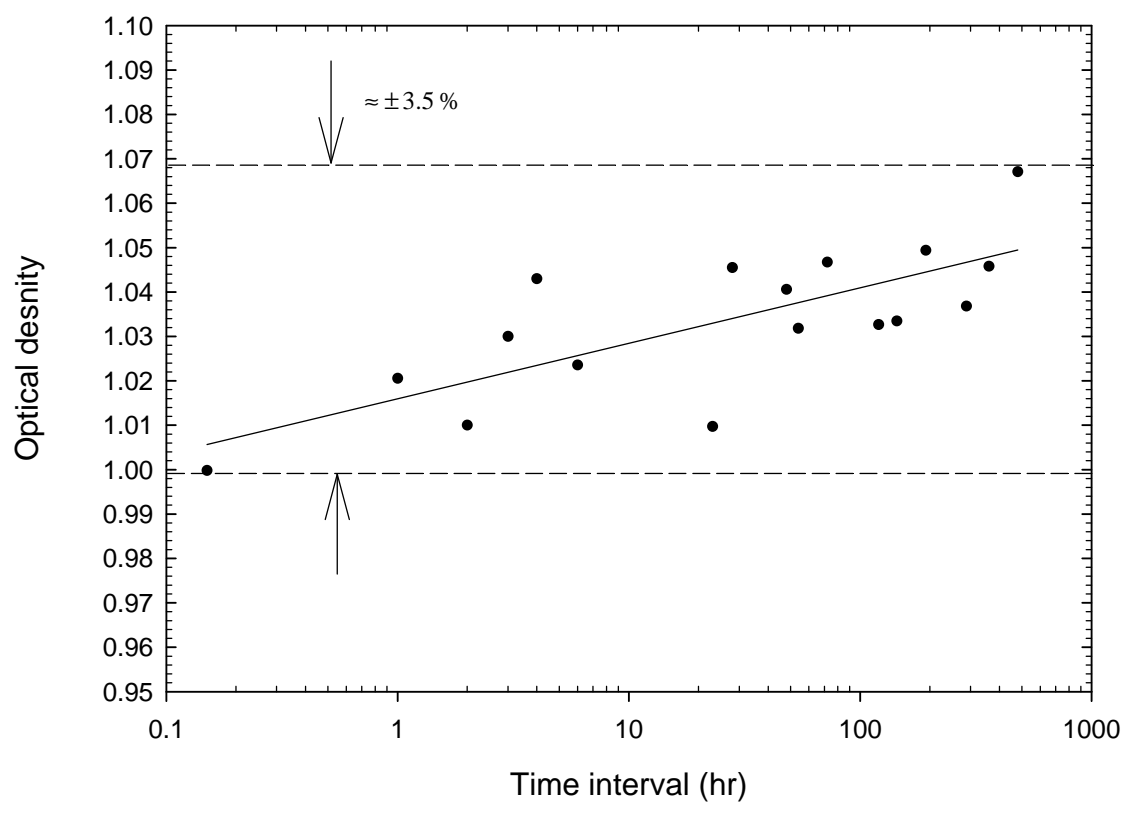

Figure 2 -Short and long term stability of the Photogem ${ }^{\circledR}$ doped Fricke solution. 


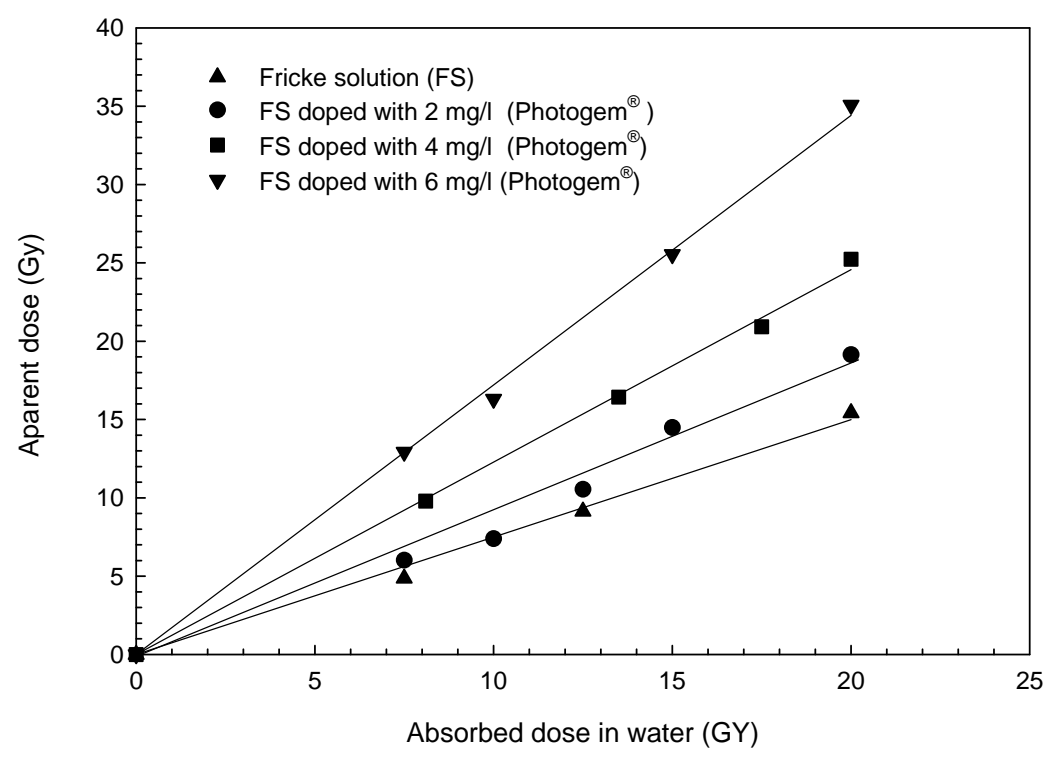

Figure 3 - Enhancement of the response of Fricke solutions doped with different concentrations of Photogem ${ }^{\circledR}$

Assuming that the Fricke solution was tissue equivalent, the concentrations of Photogem ${ }^{\circledR}$ in the Fricke solutions used in this work was close to that usually applied in a patient undergoing the PDT therapy $(1.5 \mathrm{mg}$ Photogem per $\mathrm{kg}$ patient weight (Bagnato et al, 2002). The experiments made with intravenous administration and the distribution of the photosensitizer porfimer sodium, Photofrin ${ }^{\circledR}$, through the body in clinical studies of cancer patients have shown that the mean serum concentration was of the order of 3.5 $\mathrm{mg} / \mathrm{l}$ for an injection based on $2.0 \mathrm{mg} / \mathrm{kg}$ (Bellnier and Dougherty, 1996). Such concentration was not far from those used in this work so that, by the reasons described above, a concentration of 4 $\mathrm{mg} / \mathrm{l}$ could be used for the Photogem ${ }^{\circledR}$ doped Fricke solution in the experiments involving ionization radiation.
The linear relationship between the optical densities and these concentrations irradiated with $15 \mathrm{~Gy}$ is shown in Fig. 4. The presence of Photogem $^{\circledR}$ in the Fricke solution enhances its response with the absorbed dose.

\section{Chemical reactions in the Fricke dosimeter and biological importance of some free radical species}

The Fricke dosimeter is an aqueous solution of ferrous ions in $0.4 \mathrm{MH}_{2} \mathrm{SO}_{4}$. The ionization radiation converts ferrous ions, $\mathrm{Fe}^{2+}$ into ferric ions, $\mathrm{Fe}^{3+}$, with a radiation yield, which is proportional to the absorbed dose $\left(\mathrm{D}_{\mathrm{F}}\right)$. The increase in the concentration of $\mathrm{Fe}^{3+}$ is calculated from the increase of the optical density $(\Delta \mathrm{OD})$ at $304 \mathrm{~nm}$ by the means of the Equation 1 . 


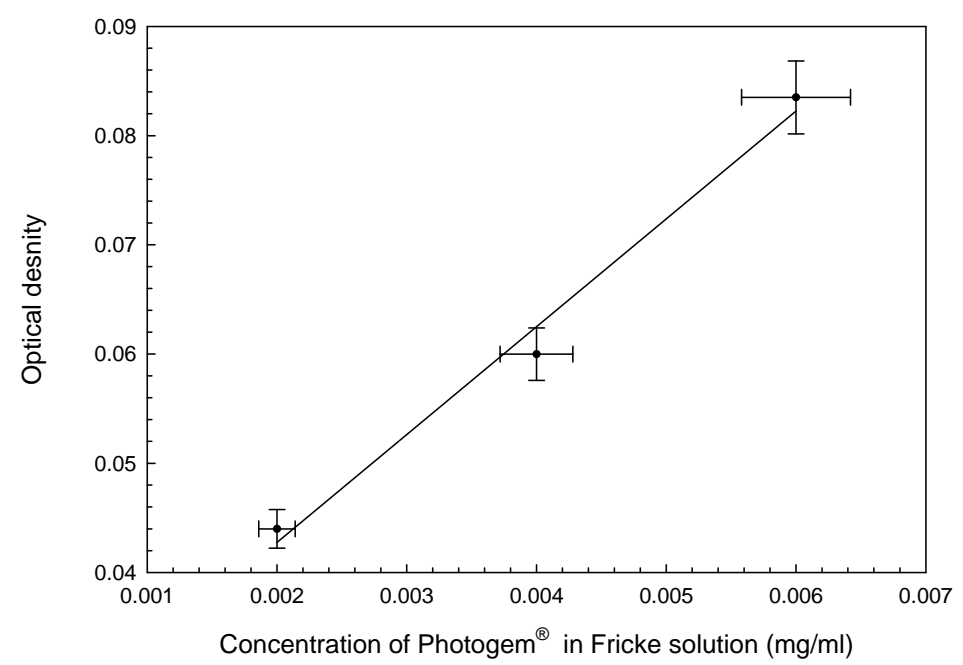

Figure 4 - Optical density as function of the concentration of Photogem ${ }^{\circledR}$ in Fricke solution irradiated with 15 Gy

The radiation yield of $\mathrm{Fe}^{3+}$ ions in an irradiated Fricke dosimeter is expressed in terms of the primary products of the radiolysis of the solution according to Equation 4 (Klassen et al., 1999).

$$
G\left(\mathrm{Fe}^{3+}\right)=2 G\left(\mathrm{H}_{2} \mathrm{O}_{2}\right)+3 G\left(\mathrm{H}^{+}\right)+G\left(\mathrm{OH}^{-}\right) \quad \text { Eq.4 }
$$

The yield of $\mathrm{Fe}^{3+}$ produced on the radiolysis of the aerated acidified $\mathrm{Fe}^{2+}$ solution gives a measure of the total yield of the reactive reducing and oxidizing species escaping the radiation track into the bulk. The kinetics and the yield of $\mathrm{Fe}^{2+}$ are determined by the reactions as below (Harris and Pimblott, 2002),

$$
\begin{aligned}
\mathrm{Fe}^{2+}+\mathrm{H} \rightarrow \mathrm{Fe}^{3+}+\mathrm{H}_{2}+\mathrm{OH}^{-} & \text {Eq. } 5 \\
\mathrm{Fe}^{2+}+\mathrm{OH} \rightarrow \mathrm{Fe}^{3+}+\mathrm{OH}^{-} & \text {Eq. } 6 \\
\mathrm{Fe}^{2+}+\mathrm{HO}_{2} \rightarrow \mathrm{Fe}^{3+}+\mathrm{H}_{2} \mathrm{O}_{2}+\mathrm{OH}^{-} & \text {Eq. } 7 \\
\mathrm{Fe}^{2+}+\mathrm{H}_{2} \mathrm{O}_{2} \rightarrow \mathrm{Fe}^{3+}+\mathrm{OH}+\mathrm{OH}^{-} & \text {Eq. } 8
\end{aligned}
$$

As can be seen from Equation 4, the radicals $\mathrm{H}_{2} \mathrm{O}_{2}$ and $\mathrm{OH}^{-}$have little effect on the yield of $\mathrm{Fe}^{3+}$ observed, as two $\mathrm{OH}$ - radicals or one $\mathrm{H}_{2} \mathrm{O}_{2}$ molecule gives two $\mathrm{Fe}^{3+}$ ions. However, both $\mathrm{H}_{2} \mathrm{O}_{2}$ the $\mathrm{OH}^{-}$radicals play an important role from the biological point of view. The hydroxyl free radical is the primary oxidizing species and can be used to oxidize and break apart the organic molecules. The hydrogen peroxide can also break apart the organic molecules through the Fenton's reaction (Satoka, 2001). Equation 8 can be broken down into a hydroxide ion and a hydroxyl free radical. Hydroxyl radical has a predominant role of the in ionizing radiation damage and minor involvement in PDT damage (Henderson and Miller, 1986), as well as in the yield of $\mathrm{Fe}^{3+}$ in the Fricke dosimeter (Eq. 4).

\section{Interaction of light and ionizing radiation with tissue and with Fricke solution doped with Photogem $^{\circledR}$}

As explained in the introduction, when light strikes an oxygenated biological medium doped with Photogem ${ }^{\circledR}$, there is a production of $\mathrm{OH}$, $\mathrm{H}_{2} \mathrm{O}_{2}, \mathrm{O}_{2}{ }^{--}, \mathrm{O}_{2}{ }^{2-}$ and ${ }^{1} \mathrm{O}_{2}$.

When ionizing radiation interacts with a medium doped with a photosensitizer, such as, Photofrin ${ }^{\circledR}$, it has been proposed (Schaffer et al., 2002) that its radiosensitivity is connect with the oligomers that can efficiently interacted (Jori, 1996) with some cytotoxic transient intermediates such as hydroxyl radicals, which are known to be generated as a result of the primary interaction of the X-ray with 
the water. In this connection, the Photofrin ${ }^{\circledR}$ acts as a radiation amplification factor, by minimizing the possible onset of the repair processes, which often limit the radio-induced cell damage (Schaffer et al., 2002). This mechanism of action has been confirmed in the case of another porphyrin, namely, gadolinium texaphyrin, which is used as a radiosensitizer (Viala et al., 1999; Rowinsky, 1999).

When light impinges in a Fricke solution doped with the Photogem ${ }^{\circledast}$, there is an enhancement in the response of the dosimeter (Austerlitz et. al., 2006). In this case, such enhancement is assumed to be due to the production of free radicals caused by the Type I reaction. When ionizing radiation strikes the Fricke solution doped with the Photogem $^{\circledast}$, as proposed by Schaffer (2002), there is a radiation amplification factor (here assumed to be amplification of free radials) associated with the production of the light, including Bharat energies that can excite the electrons (Padmanabha-Rao, 2001), a kind of Type III reaction, which enhances the Fricke dosimeter response.

\section{Tumor growth inhibition and Fricke dosimeter enhancement}

The effects of the hematoporphyrin derivative, light, and ${ }^{60} \mathrm{Co}$ irradiation in a rat glioma model, using an in vivo and an in vitro clonogenic assay, have been reported by Kostron (1986). It was fond that ${ }^{60} \mathrm{Co}$ irradiation in the presence of an hematoporphyrin derivative produced a significant tumor growth inhibition (up to about 50\%) and this growth inhibition was directly related to the concentration of the hematoporphyrin derivative. This result corroborated with observations in a recent publication by Schaffer et al. (2002b) where Photofrin ${ }^{\circledR}$ II (an hematoporphyrin derivative produced by the AXCAN INC - Canada and equivalent to Photogem ${ }^{\circledR}$ ) was used as a specific radiosensitising agent in the patients with the bladder cancer (Sokolov, 1995). They observed that in similar conditions, the patient injected with $1 \mathrm{mg} / \mathrm{kg}$ had a noticeable increase on the radiotherapy response. They claimed a $40 \%$ reduction of the tumors after the radiotherapy due to the presence of the porphyrin. Also, experimental work using animals have shown that the time for tumor to recover to the original size after a certain dose of the radiation is increased by almost a factor of two when the Photofrin ${ }^{\circledR}$ II is used as an enhancement agent for the radiotherapy (Schaffer et al., 2001).

Henderson (1986) reported the involvement of free radical species in the process of cell killing by comparing the effect on cell survival following photodynamic therapy and gamma irradiation. Apparently $90 \%$ of the radiotoxic effects could be due to the indirect effects of radiation (Walicka, 2000). In this work pronounced enhancement of the Photogem ${ }^{\circledR}$ doped Fricke solution response and its direct relationship with the concentration of the hematoporphyrin derivative was found. This suggested that a Fricke solution doped with photosensitizer under X-rays irradiation not only detected the free radicals produced by the water hydrolysis, but also those from the Type I reaction. Therefore, such a dosimeter could be used to evaluate the amount of the free radicals produced by a particular photosensitizer and its correlation with the indirect mechanisms of radiation in phototherapy combined with the radiotherapy.

The Fricke solution could also be used in the determination of the concentration of the Photogem ${ }^{\circledR}$ in conventional PDT application. The combination of the light together with the ionization radiation could eventually reveal the level of the light dose necessary to promote the desired level of the free radical formation that can be used in the development of a PDT dosimeter as well as the possible degradation of a photosensitizer with the ionizing radiation, which can be done by irradiating the solution with light and ionizing radiation and vice versa. This is a subject that still demands a considerable investigation and it is under investigation by our group. No further study was done concerning the overall uncertainty in the determination of absorbed dose. However, the reproducibility of the Fricke dosimeter did not exceed $\pm 2.5 \%$ (Souza and Austerlitz, 2005) and the accuracy in the absorbed dose determination with ionization chambers was in the order of $\pm 3.5 \%$. The precision in the measurements done with the Photogem ${ }^{\circledR}$ doped Fricke solution measurements was $\pm 3.5 \%$ ( $1 \mathrm{sd})$.

\section{CONCLUSIONS}

From the results, the following conclusions could be drawn: 
- Under the irradiation with the ionizing radiation, there was an enhancement in the response of the Fricke solution doped with the Photogem ${ }^{\circledR}$ which was proportional to the concentration of the photosensitizer;

- as the mechanism behind the Fricke dosimetry was the formation of the free radicals, the enhancement of the response of the Photogem $^{\circledR}$ doped Fricke solution was attributed to the Type I reaction, and

- Fricke solution doped with the photosensitizer could also be used to compare the production of some free radicals from different radiosensitizers under the irradiation with ionizing radiation.

\section{RESUMO}

Tubos de ensaio foram preenchidos com a solução Fricke dopada com Fotogem ${ }^{\circledR}$ em concentrações crescentes; essa hemotoporfirina é utilizada na terapia fotodinâmica. Esses tubos foram irradiados com doses de 5 a 20 Gy. A solução Fricke convencional também foi irradiada com as mesmas doses. As concentrações de íons férricos nas soluções Fricke convencional e dopadas irradiadas foram medidas num espectrofotômetro com comprimento de onda entre 220 e $340 \mathrm{~nm}$. Os resultados mostraram que quando comparado o Fricke convencional com o Fricke dopado irradiado, as amostras dopadas demonstraram um aumento na resposta da dose absorvida que é proporcional a concentração do Photogem ${ }^{\circledR}$ na solução Fricke. Concluímos que esse procedimento pode ser utilizado para propósitos de dosimetria na terapia com radiossensibilizadores .

\section{REFERENCES}

Attix, F.H. (1986), "Introduction to Radiological Physics and Radiation Dosimetry", WileyIntersciende Publication, USA.

Austerlitz, C., Mota, H., Souza, V., Campos, D., Bagnato, V., Allison, R. and Sibata, C., (2006), "The use of Fricke solutions to assess light dose in photodynamic therapy (PDT)", AAPM $48^{\text {th }}$ Annual Meeting, Orange County Convention Center, Orland, Fl, July 30 - August 3.
Bagnato, V. S.; Marcassa, L. G.; et al. (2002), "Practical guide in photodynamic therapy for the treatment of tumors" (In Portuguese). São Carlos, Brazil, Centro de Pesquisas em Óptica e Fotônica Universidade de São Paulo - Instituto de Física de São Carlos.

Bellnier D. A. and Dougherty TJ. (1986), "Haematoporphyrin derivate photosensitization and $\mathrm{X}$-radiation damage interaction in Chinese hamster ovary fibroblasts". Int. J. Radiat. Biol, 50, 659-64.

Bellnier, D. A. and Dougherty, T. J. (1996). "A preliminary pharmacokinetic study of intravenous Photofrin in patients". J. Clin. Laser Med. Surg. 14, n. 5, 311-314.

Benstead, K. and Moore, J. V. (1990). "The effect of combined modality treatment with ionising radiation and TPPS-mediated photodynamic therapy on murine tail skin". Br. J. Cancer, 62, n. 1, 48-53.

Chen, D. Y. (1985), "The use of hematoporphyrin derivative $(\mathrm{HpD})$ as a sensitizer to radiation therapy in treatment of S 180 mice". Treat. Laser, 5, 137.

Colasanti A., Kisslinger A., Quarto M. and Riccio P. (2004), "Combined effects of radiotherapy and photodynamic therapy on an in vitro human prostate model", Acta Biochimica Polonica, 51, n. 4, 10391046.

Dougherty, T. J. (1993), "Photodynamic therapy." Photochem. Photobiol., 58, n. 6, 895-900.

Fritsch, C. and Ruzicka, T. (2003), "Fluorescence Diagnosis and Photodynamic Therapy of Skin Diseases, Atlas and Handbook", ISBN 3-211-838279, Springer Wien, New York.

Harris R. E. and Pimblott, S. M. (2002), "On ${ }^{3} \mathrm{H} \beta$ Particle and ${ }^{60} \mathrm{Co} \gamma$ Irradiation of Aqueous Systems". Radiat. Res., 158, n. 4, 493-504.

Haylett A. K., Ward T. H. and Moore J. V. (2003), "DNA damage and repair in Gorlin syndrome and normal fibroblasts after aminolevulinic acid photodynamic therapy: a comet assay study". Photochem. Photobiol., 78, n. 4, 337-341.

Henderson B.W and Miller A.C. (1986), "Effects of scavengers of reactive oxygen and radical species on cell survival following photodynamic treatment in vitro: comparison to ionizing radiation". Radiat. Res., 108, n. 2, 196-205.

International Atomic Energy Agency (1977), "Manual of Food Irradiation Dosimetry", TRS 178, IAEA, Vienna.

International Commission on Radiation Units and Measurements (1970), "Radiation dosimetry: X-Rays Generated at Potententials of 5 to $150 \mathrm{kV}$ ", ICRU Publications, Washington DC, USA.

Jori, G. (1996). "Tumor Photosensitizers: approach to enhance the efficiency and selectivity of photodynamic therapy", J. Photochem. Photobiol. B, 36, 87-93. 
Klassen; N. V., Shortt, K. R.; et al. (1999), "Fricke dosimetry: the difference between $\mathrm{G}(\mathrm{Fe} 3+)$ for $60 \mathrm{Co}$ gamma-rays and high-energy x-rays." Phys Med Biol 44, n. 7, 1609-1624.

Kostron, H.; Swartz, M. R.; Miller, D. C.; Martuza R. L. (1986), "The interaction of hematoporphyrin derivative, light and ionizing radiation in a rat glioma model". Cancer (Phila.), 57, 964-970.

Lukšienè, Z. (2004), "Experimental evidence on possibility to radiosensitize aggressive tumors by porphyrins" Medicina Kaunas, 40, n. 9, 868-874.

Moan J. and Petersen E.O. (1981), "X-irradiation of human cells in culture in the presence of haematoporphyrin". Int. J. Radiat. Biol., 40, 107-109.

Oleinick, N. L. and Evans H. H. (1998), "The photobiology of photodynamic therapy: cellular targets and mechanisms." Radiat. Res. 150, n. 5, 146156.

Olszanski, A.; Klassen, N. V.; Ross, C. K. and Shortt, K. R., (2002), "The IRS Fricke Dosimetry System", Institute for National Measurement Standards, National Research Council, PIRS-0815, Ottawa, Ontario.

Padmanabha-Rao, M. A. (2001), "Discovery of light emission from XRF sources", Paper presented at $50^{\text {th }}$ Annual Denver X-ray Conference, Steamboat Springs, July 30 to August 3, F-01, XRF session, August 1, page 124 in Volume of Abstracts.

Rowinsky, E. K. (1999), "Novel Radiation sensitizers targeting tissue hypoxia", Oncology, 13, 61-70.

Schaffer, M.; Schaffer, P. M., et al. (2001)., "Photofrin II as an efficient radiosensitizing agent in an experimental tumor." Onkologie, 24, n. 5, 482-485.

Satoka, A.; Makoto, Y.; Takehiro, M. and Kiyotaka, S. (2001), "Clarification of Enhanced Hydroxyl Radical Production in Fenton Reaction with ATP/ADP Based on Luminol Chemiluminescence", Journal of Chemical Engineering of Japan, 34, n. 7, 956-959.

Schaffer, M.; Schaffer, P. M.; et al. (2002). "Photofrin as a specific radiosensitizing agent for tumors: studies in comparison to other porphyrins, in an experimental in vivo model." J. Photochem. Photobiol., 66, n. 3, 157-164.

Schaffer, M.; Schaffer, P. M.; et al. (2002). "Application of Photofrin II as a specific radiosensitising agent in patients with bladder cancer-a report of two cases." Photochem. Photobiol. Sci. 1, n. $9,686-9$.
Schaffer, M.; Ertl-Wagner B.; et al. (2003). "Porphyrins as radiosensitizing agents for solid neoplasms." Curr. Pharm. Des., 9, n. 25, 2024-35.

Schaffer, M.; Ertl-Wagner, B.; Schaffer, P. M.; Kulka, U.; Jori, G.; Duhmke, E. and Hofstetter A. (2005), "The Application of Photofrin II® as a Sensitizing Agent for Ionizing Radiation-A New Approach in Tumor Therapy?" Current. Medicinal Chemistry, 12, n.10, 1209-1215(7).

Sibata, C. H.; Colussi, V. C.; et al. (2000), "Photodynamic therapy: a new concept in medical treatment." Braz. J. Med. Biol. Res. 33, n. 8, 869-80.

Sokolov, V. V.; Stranadko, E. F.; et al. (1995), "The photodynamic therapy of malignant tumors in basic sites with the preparations photohem and photosens (the results of 3 years of observations)." Vopr. Onkol. 41, n. 2, 134-8

Souza, V. L. B. and Austerlitz, C. (2005), Determinação de $\mathrm{NH} 4 \mathrm{Fe}(\mathrm{SO} 4) 2$ em solução Fricke com o espectrofotômetro beckman DU 640. Paper presented at 1o. Congresso Brasileiro de Proteção Radiológica, Hotel Glória, Rio de Janeiro, Brazil.

Viala, J.; Vanel, D.; Meingan, P.; Lartigau, E.; Garde, P. and Renschler, M. (1999), "Phases IB and II multidose trial of gadolinium texaphyrin, a radiation sensitizer detectable at MR imaging: preliminary results in brain metastases", Radiology, 212, 755-759.

Walicka, M. A.; Ding, Y.; Adelstein, S. J. and Kassis A. I., (2000), "Toxicity of DNA-Incorporated Iodine125: Quantifying the Direct and Indirect Effects Radiation", Research, 154, 3, 326-330.?

Wilson, B. C. (2002), "Photodynamic therapy for cancer: principles." Can. J. Gastroenterol. 16, n. 6 393-396.

Zhang, W; Anker, L.; Low, R. E.; Hinton, D. R.; Gopalakrishna, R.; Pu, Q.; et al. (1996), "Enhancement of radiosensitivity in human malignant glioma cells by hypericin in vitro". Clin. Cancer Res., 2, 843-846.

Zhao, F. Y.; Zhang, K. H.; Huang, H. N.; Sun, K. H.; Ling, Q. B.; Xu, B. (1986), "Use of haematoporphyrin derivative as a sensitizer for radiotherapy of oral and maxillofacial tumours: a preliminary report”. Lasers Med. Sci., 1, 253-6. 